\title{
Factors Determining Citizen's Attitudes Towards Agri-Environmental Property Rights
}

\author{
Esperanza Vera-Toscano • José A. Gómez-Limón • \\ Eduardo Moyano · Fernando Garrido
}

Accepted: 28 March 2008 / Published online: 3 May 2008

(C) Springer Science+Business Media B.V. 2008

\begin{abstract}
The purpose of this paper is to contribute further insights into individuals' agri-environmental attitudes. In particular, the empirical analysis focuses on how citizens think agri-environmental property rights should be assigned. This has been done by surveying how individuals consider the environmental policy should promote the implementation of a group of agri-environmental measures, allowing us to examine the determinants of individuals' opinions about this matter. Results indicate that higher level of income and education support the implementation of obligatory agri-environmental measures with no financial support (property rights should rest on society) except for measures to improve public access to land for leisure activities and ecological farming which are seen more of the voluntary kind (property rights should rest on farmers). Additionally, rural residency has strong significant effect on agri-environmental attitudes as rural residents are more likely to support the implementation of voluntary (with/without financial support) agri-environmental measures. On the whole, this research proves to be a valuable tool to identify factors determining individuals' attitudes towards agri-environmental property rights which can certainly help policymakers to provide customized, better response to social demands on this matter.
\end{abstract}

Keywords Agri-environmental policy · Property rights · Environmental implications · Institutional Economics · Citizen's attitudes

\section{Introduction}

Traditionally, the role of agriculture has been to produce food and fiber so as to fulfill the basic needs of a growing population. Since the beginning of the 20th century and once

E. Vera-Toscano $(\bowtie) \cdot$ E. Moyano $\cdot$ F. Garrido Instituto de Estudios Sociales Avanzados, Consejo Superiorde Investigaciones Científicas (IESA-CSIC), Campo Santo de losMártires, 7, 14004 Cordoba, Spain e-mail: evera@iesa.csic.es

J. A. Gómez-Limón

Dpto. de Economía Agraria, E.T.S.II.AA. Palencia.Universidad de Valladolid, Valladolid, Spain 
agricultural land use cannot be extended any further, we have witnessed an intensification of food production through the use of fertilizers and improved machinery, and via genetic development and pesticides. This significant technological growth, particularly in developed countries, has been especially supported by the implementation of a friendly and very successful productivist agricultural policy. However, the prodigious rise of agricultural production has also been accompanied by important negative environmental implications; soil quality deterioration (erosion, salinity, and chemical pollution), contamination of the atmosphere by methane, nitrous oxide, and ammonia derived from livestock and fertilizers, and water pollution by different agrochemicals, harming wildlife and human health are notorious examples (OECD 1998).

Notwithstanding, it can be argued that the negative environmental implications of agriculture have not been of social concern until very recently. In the 1970 s, agriculture activity was seen as being in complete harmony with nature, playing a strategic economic role within societies as a provider of food and income among the rural population. This phenomenon was called the exceptionality status of agriculture, which moved the environmental debate towards industrial and urban contamination (Whitby 1996). However, the past two decades have witnessed a shift in the pattern of demand for goods produced by agriculture as more people have felt frustrated by agriculture-environment interactions. Agricultural activity in developed countries began in the post-productivist era (Ilbery and Bowler 1998), which entails a significant change in the social contract that determines its performance. Increasing wealth, mobility, and leisure time have all acted to increase the marginal value of environmental and amenity goods relative to the marginal value of food and fiber. The supply of goods such as scenic landscapes, wildlife, and biodiversity has gained importance. As a result, we have witnessed the growth of a rural environmental movement and the development of a more visible agri-environmental policy. Agriculture activity has consequently lost this exceptionality status. Since the $1980 \mathrm{~s}$, and more intensively the $1990 \mathrm{~s}$, various government agencies (regional, national, and the European Union) have embarked upon the implementation of an active agri-environmental policy, with the European Union Regulation CE 1698/2005 on rural development being one of the most recent developments.

Thus, research interest has moved from an initial focus on quantification of uptake (i.e., through profiling of agri-environmental scheme participants), to a better understanding of the attitudes, motivation, and behavior of participants, mostly farmers, and nonparticipants, citizens in general (Morris and Potter 1995; Wilson 1996; Wilson and Hart 2001). Nevertheless, to our knowledge, empirical research into citizens' attitudes in relation to the implementation of a particular agri-environmental policy has been very scarce if not absent.

The purpose of this paper is thus to contribute further insights into individual agri-environmental attitudes. In particular, the empirical analysis focuses on the agri-environmental property rights as social institutions upon which agriculture-environment-society interactions are based. Property rights determine who can do what with a particular resource and how they can do it. Therefore, gaining a better understanding of on individuals' perceptions of agri-environmental property rights will be of particular relevance to policy-makers as it will help raise knowledge about the issues faced in redefining the new agriculture. Ultimately, this research is likely to contribute to agri-environmental policy evaluation and development.

To do so, this paper uses the 2005 "Survey on Individuals' Opinion of Rurality and Agriculture in Andalusia (Agrobarometre 2005)" (IESA 2006). The survey is intended as a snapshot of individuals' preferences for and opinions on different functions of agriculture. It further includes individual data on demographic and socioeconomic characteristics. The research was carried out within a particular geographical area, the Autonomous Region of Andalusia (Southern Spain). The interest of this research lies both in its approach, which emphasizes 
the need to consider citizens' opinion for public policy evaluation, and its methodology based on a opinion poll, which can be employed in any geographical area when subjective studies (i.e., small number of qualitative interviews) are not sufficiently convincing to inform the policy-making process reliably.

The plan of the paper is as follows. In the next section, we present and discuss the concept of property rights and the environmental implications of agriculture, as well as the potential determinants of agri-environmental concern and their effect on citizens' attitudes towards agri-environmental property rights. Section 3 describes the available data and considers the empirical specification of the econometric models used for the analysis. Section 4 reports the estimation results on the multivariate analysis, while Sect. 5 concludes.

\section{Property Rights and the Environmental Implications of Agriculture: Review of Issues and Concepts}

When farmers agree to reduce chemical applications, or to implement practices that will prevent the erosion of precious soil (either on a voluntary or mandatory basis), such actions can be interpreted as an example of civic-minded behavior that will provide valuable environmental benefits to the public at large. For these actions, farmers often believe that gratitude should be forthcoming, if not financial rewards (Bromley and Hodge 1990). We know that agricultural policy in many developed countries indeed provides financial rewards for farmers who undertake land-use practices that protect environmental attributes. Such payments are evidence that - at least in political terms - their actions are regarded as providing these beneficial effects. ${ }^{1}$ The other side of the argument would suggest, however, that regulation and control alone should dominate environmental policy. Regulations compel polluters to adhere to restrictions on either the level of pollution, the type of activities that may be practised, or the type of technologies that may be used. If industrial polluters are often required to pay for their environmental implications, why should farmers not face the same financial disincentive? Great difficulty arises from a general confusion in the matter of whether particular environmental-friendly agricultural techniques and practices provide benefits or just prevent harm (Ortiz and Estruch 2004; Whitby 2000). That is, differing perceptions of the environmental implications of agriculture motivate much of the struggle in the agriculture-environment-society interactions and the consequent development of an appropriate agri-environmental policy.

Therefore, there is a need to reconsider the way we (as individuals and citizens) think of agriculture, the environment, and society in general. To do so, we must first describe and characterize the environmental implications of agriculture, to further disentangle what produces the struggle among competing visions of the public interest over the correct policy response to agri-environmental problems, that is, whether the instruments for achieving agrienvironmental goals should be command and control mechanisms only, should be accompanied by economic incentives, or should be simply adopted on a voluntary basis. This entails considerations of property rights for land and other resources used by the agricultural sector, and the redefinition of acceptable reference levels against which deviations are to be rewarded or penalized.

\footnotetext{
1 For this topic see Oñate et al. (1998) and Ortiz and Ceña (2002) for an analysis of the degree to which the EU agro-environmental schemes have been implemented in Spain. In this sense, it is also worth mentioning the works of Primdahl et al. (2003) and EEA $(2004,2006)$ for their implementation in the EU. See also Clark et al. (1997) and Buller et al. (2000) for an evaluation of EU agri-environmental policy implementation.
} 
Following Bromley (1996), the environmental implications of agriculture can be summarized in three types. This classification is explained by considering that agriculture in industrialized nations represents an essential way to accomplish three important public functions-besides producing food and fiber:

1. Habitat implications of agriculture reflect its role regarding the maintenance of plants and animals that are not part of the agriculture enterprise, although they are located inside the farms (i.e., birds, small mammals or native plants). Agricultural activity can contribute by providing habitats for a variety of wildlife, adding to the diversity of the landscape.

2. Ecological process implications related with the general integrity of rural areas. This concept includes those aspects of agriculture activity that affect, positively or negatively, ecological processes beyond the boundary of the farm. Contamination of downstream rivers and lakes by agricultural chemicals are examples of this kind of implications.

3. Amenity implications concern visual aspects of the rural countryside that make it pleasant (or unpleasant) to the eye. The rural landscape is both created and managed by agriculture, and this rural character is important in its own right. This serves to remind us that agriculture produces both commodities and amenities (Bromley and Hodge 1990).

While these environmental implications of agriculture cannot possibly represent mutually exclusive categories, considering them in this light allows us to focus on important policy dimensions that might otherwise be obscured.

Controversy arises when farmers, driven by the economic pressures of agricultural production, may destroy particular habitats, ecological processes or visual aspects of the rural countryside that the public has come to value. In this setting, the public is disinclined to grant the argument that, as the owner of the land, the farmer is free to do as they please. In this sense, there is a range of land uses that should no longer be permitted, even though at one time- under other socioeconomic conditions - those particular uses were thought to be acceptable. This current situation reflects the changing social perceptions of ownership, implying a change in the current status quo with a significant loss of agricultural producers' degree of freedom (Fig. 1).

While landowners' claims will often be in terms of so-called natural rights and individual freedom, property rights ${ }^{2}$ are neither absolute nor unconditional but justified by purpose, and limited by necessity (Christman 1994). Quoting Tawney:

The individual has no absolute rights; they are relative to the function which he performs in the community of which he is a member [...]. All rights, in short, are conditional and derivative, because all power should be conditional and derivative. They are derived from the end or purpose of the society in which they exist. They are conditional on being used to contribute to the attainment of that end, not to thwart it. And this means in practice that, if society is to be healthy, men must regard themselves not as the owners of rights, but as trustees for the discharge of functions and the instruments of a social purpose (Tawney 1948, p. 51).

\footnotetext{
2 By property rights we mean the formal and informal institutions and arrangements that govern access to land and other resources, as well as the resulting claims that individuals have on those resources and on the benefits they generate (Bromley 1997). These property rights determine who can do what with a particular resource, such as a piece of land, and how they can do it. Property rights arise from law, custom, and market operation, changing continuously as social preferences change. Public and government agencies play a central role in shaping these property rights. Given their key role in determining how income and wealth are generated and distributed, it is not surprising that property rights are subject to permanent controversy and debate. In any case, it is clear that the ways in which property rights are defined and distributed is a key issue to achieve an efficient and equitable use of resources on which sustainable development can be based (World Bank 1997).
} 


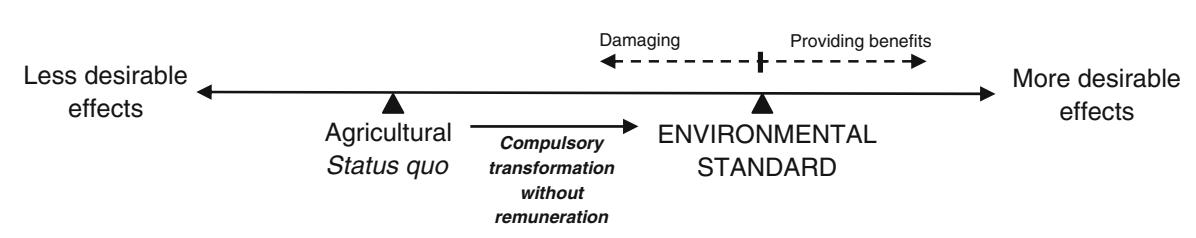

Fig. 1 Application of an environmental standard. Source: Adapted from Ortiz and Estruch (2004)

Once the idea that property rights are derivative and limited is clear, the appropriate definition of property rights requires the establishment, in the political arena, of acceptable reference levels against which deviations are to be rewarded or penalized.

However, this is not an easy task. The environmental debate in the agricultural sector is characterized by two main issues. First, problems arise because the very idea of environmental harm is often unclear, and simple rules are clouded by operational realities. Thus, there is a sense of certitude to the idea that those who cause harm should pay for it, but the difficulty, however, may be to ascertain precisely who causes this harm. Second, while the concept of property rights as derivative and limited is well accepted in theory, visions of property rights as some absolute construct still loom large in public policy discourse concerning the environment. This idea underlies much agricultural policy where antisocial land-use activities are often necessarily modified by the payment of inducements to farmers to adopt alternative practices (Bromley and Hodge 1990; Moyano and Garrido 1996). Such payments serve to reinforce the idea that farmers have a right to allow topsoil to wash away, to drain wetlands, or to apply toxic chemicals. The myth of absolute property rights affirms some environmental practices, which must then be paid for.

This discussion explains much of the disagreement over the correct policy response to the environmental implications of agriculture which arises from the different perceptions about property rights inherent in land across the various interest groups. It confirms Tawney's approach of property rights as a social construction:

Property was to be an aid to creative work, not an alternative to it... The law of the village bound the peasant to use his land, not as he himself might find most profitable, but to grow the corn the village needed... . Property reposed, in short, not merely upon convenience, or the appetite for gain, but on a moral principle. It was protected not only for the sake of those who owned, but for the sake of those who worked and of those for whom their work provided. It was protected, because, without security for property, wealth could not be produced or the business of society carried on. (Tawney 1948, pp. 59-60).

This means that different interest groups-with differing and conflicting visions of public goods and ever-changing preferences-will have different ideas about how agrienvironmental property rights should be allocated. One option is to consider that property rights should belong to farmers, allowing them to put in place environmental measures and good practices on a voluntary basis as they desire. On the contrary, other people could believe that the best option is to allocate these rights to society, allowing the penalization of any behavior which could cause an environmental harm (with the implementation of agrienvironmental measures being mandatory for farmers with or without financial support). Of course, intermediate or mixed considerations can also be considered.

Since as already mentioned, policy making in democratic systems implies a constant struggle among competing visions of the public interest, having a detailed understanding 
of citizens' attitudes towards agriculture-environment interactions (i.e., agri-environmental sensibility/concern under different property rights regimes) may be of interest to design policy initiatives. In so doing, this may help to promote uptake and foster desirable social developments that will ensure the use and management of the agricultural and rural environment in an efficient and equitable manner. To this task we will devote the remainder of the paper.

\section{Data and Empirical Specification}

\subsection{The Opinion Survey}

The dataset used in this research was derived from the "2005 Survey on Individuals' Opinion of Rurality and Agriculture in Andalusia-Agrobarometre 2005” (IESA 2006), a household survey conducted in 2005 by the Institute of Advanced Social Studies (IESA-CSIC) in Spain with funding from the Department of Agriculture and Fisheries of the Andalusian Regional Government on a representative sample of 1,168 individual respondents. ${ }^{3}$ The target population was all people living in Andalusia aged 18 years and over ( 7.6 million people), and the survey was designed to capture individuals' opinions on rural and agriculture-related issues. In particular, this year of the survey investigates for the first time the relevance of agri-environmental property rights as dynamic social institutions upon which the agriculture-environment-society relationship is based. Responses were analyzed to obtain deeper insights into the agri-environmental attitudes of individual citizens.

In the survey, individuals were asked about different agri-environmental techniques and good practices and how they think they should be implemented by farmers (see Table 1 for further details). The answer to this question was coded into four categories (nominal values) ${ }^{4}$ as follows: (1) "It is up to the farmer to implement the selected agri-environmental measure, however, if he does so, he should be rewarded for the provision of such a benefit to the larger public" (voluntary with financial support, VFS); (2) "It is up to the farmer to implement the selected agri-environmental measure, however, if he does so, he will not be rewarded for the provision of such a benefit to the larger public" (voluntary without financial support, VNFS); (3) "The implementation of these techniques should be obligatory for farmers with financial support" (obligatory with financial support, OFS), and (4) "The implementation of these techniques should be obligatory for farmers with no financial support" (obligatory without financial support, ONFS).

Up to seven agri-environmental techniques and good practices were included in the questionnaire, namely (see Table 1 for further details on how the question was asked):

1. Techniques to reduce soil erosion

2. Techniques to preserve flora and fauna

\footnotetext{
${ }^{3}$ The sample was drawn using a stratified, multistage design using probability sampling. The principal stratification of the sample takes place by socioeconomic groups within census units. Census units were randomly selected ensuring representation of those individuals aged 18 years and above. Households were selected within census units accounting for a gender and age quota. To avoid underrepresentation of densely populated households, results were weighted according to the 2001 National Census.

${ }^{4}$ Questions were asked in the survey in very general terms not conditioning the response. The empirical specification applied allowed us to control for individual observed heterogeneity only. Given the characteristics of the survey, it is outside the scope of this paper to control for any kind of unobservable characteristics of the individuals. Thus, we cannot say anything on how preferences, expectations, and/or beliefs were individually formed in this matter.
} 
Table 1 Question included in the survey to capture individuals' attitudes towards the establishment of different agri-environmental measures

Question. As you may know, agricultural production has important environmental implications both positive (e.g., traditional landscape conservation), and negative (e.g., erosion or chemical pollution). In order to improve the relationship between agriculture production and the environment, farmers could put in place different agri-environmental measures and good practices. Please, indicate (among the options below) how do you think the current environmental policy should promote the implementation of the following environmental measures:

1. "It is up to the farmer to implement the selected agri-environmental measure, however, if he does so, he should be rewarded for the provision of such a benefit to the larger public" (voluntary with financial support, VFS);

2. "It is up to the farmer to implement the selected agri-environmental measure, however, if he does so, he won't be rewarded for the provision of such a benefit to the larger public" (voluntary without financial support, VNFS);

3. "The implementation of these techniques should be obligatory for farmers with financial support" (obligatory with financial support, OFS); and

4. "The implementation of these techniques should be obligatory for farmers with no financial support" (obligatory without financial support, ONFS).

\begin{tabular}{|c|c|c|c|c|}
\hline \multirow[t]{2}{*}{$\begin{array}{l}\text { Agri-environmental } \\
\text { measures }\end{array}$} & \multicolumn{4}{|c|}{$\begin{array}{l}\text { How do you think the current environmental policy should promote } \\
\text { the implementation of these agri-environmental measures? }\end{array}$} \\
\hline & (1) & (2) & (3) & (4) \\
\hline $\begin{array}{l}\text { Techniques to reduce soil } \\
\text { erosion }\left(\mathrm{AEM}_{1}\right)\end{array}$ & $\square$ & $\square$ & $\square$ & $\square$ \\
\hline $\begin{array}{l}\text { Techniques to preserve } \\
\text { flora and fauna }\left(\mathrm{AEM}_{2}\right)\end{array}$ & $\square$ & $\square$ & $\square$ & $\square$ \\
\hline $\begin{array}{l}\text { Methods to improve the } \\
\text { application of fertilizers } \\
\text { and pesticides }\left(\mathrm{AEM}_{3}\right)\end{array}$ & $\square$ & $\square$ & $\square$ & $\square$ \\
\hline $\begin{array}{l}\text { Techniques to improve } \\
\text { water use in agriculture } \\
\left(\mathrm{AEM}_{4}\right)\end{array}$ & $\square$ & $\square$ & $\square$ & $\square$ \\
\hline $\begin{array}{l}\text { Measures for landscape } \\
\text { conservation }\left(\mathrm{AEM}_{5}\right)\end{array}$ & $\square$ & $\square$ & $\square$ & $\square$ \\
\hline $\begin{array}{l}\text { Measures to improve } \\
\text { access to land for leisure } \\
\text { activities }\left(\mathrm{AEM}_{6}\right)\end{array}$ & $\square$ & $\square$ & $\square$ & $\square$ \\
\hline $\begin{array}{l}\text { Promotion of } \text { organic } \\
\text { farming }\left(\mathrm{AEM}_{7}\right)\end{array}$ & $\square$ & $\square$ & $\square$ & $\square$ \\
\hline
\end{tabular}

3. Methods to improve the application of fertilizers and pesticides

4. Techniques to improve water use in agriculture

5. Measures for landscape conservation

6. Measures to improve public access to land for leisure activities

7. Promotion of organic farming

These seven agri-environmental measures (which acronym will be $A E M_{j i}$ with $j=1, \ldots, 7$ ) were selected mainly for two reasons: (a) Most of them have already been promoted on different agri-environmental programs in Andalusia; and (b) they are related to Bromley's classification of the agri-environmental implications of agriculture. Thus, techniques 1 and 2 refer to habitat implications of agriculture, while 3 and 4 comprise ecological implications and, 5 and 6 include amenity ones. Lastly, we have included the promotion of organic farming (technique 7) as a good practice that goes beyond any agri-environmental implication as it can potentially affect other aspects of life such as consumers' health. 
Given the discrete nature of the answer, we assume that such an answer is meaningful and comparable between individuals (Clark 1997; Ferrer-i-Carbonell and Frijters 2004) providing interesting and plausible results that cover the ample spectrum on differing individuals' attitudes towards the environmental implications of agriculture under different property rights regimes. Results will vary from those who think that voluntary schemes with financial rewards should be designed and implemented to promote farmers' provision of agri-environmental benefits to the larger public (i.e. property rights should rest with farmers), to those who believe that farmers should not have to be paid for providing agri-environmental benefits which in the absence of agriculture would be provided without any compensation requirement, resulting on environmental-friendly practices that should be obligatory in the agricultural sector (i.e. property rights should rest with the society). Thus, citizens answering these questions reveal their preferences about who should own the property rights over the agriculture resources considered (farmers or society).

Descriptive empirical results on individual's attitudes towards the desirable implementation of agri-environmental property rights are presented in Table 2 . Overall, we perceive a strong social awareness on this issue as $64.6 \%$ of our sample thinks these agri-environmental measures should be obligatory for farmers (property rights should mainly rest with society). Conversely, $18.3 \%$ of the sample believes that the implementation of these techniques and practices might be voluntary (property rights should mainly rest with farmers). The remaining $17.1 \%$ does not give any answer. Nevertheless, it is also worth pointing out that a large majority of Andalusians (70.2\%) think that these measures should be implemented by providing farmers some financial support, while only $12.7 \%$ of our sample agrees implementation should be done with no financial support for farmers. ${ }^{5}$ This general opinion on the promotion of compulsory but subsidized agri-environmental measures reflects that individuals believe agri-environmental property rights should rest with the society so as to improve its welfare. In any case, this consideration should not be interpreted in absolute terms as they also believe that such an obligation implies a change on the current status quo (property rights currently resting on farmers) with a significant loss for farmers, who should then be compensated for it.

While overall results are interesting, it is equally useful to study whether or not significant differences exist between the various agri-environmental measures under study. Results indicate how the implementation of obligatory measures is more strongly felt ( $\chi^{2}=449.7$; $\mathrm{df}=$ $24 ; p<0.001)$ for those techniques to improve water use in agriculture $(79.0 \%)$, followed by techniques to preserve flora and fauna $(69.6 \%)$, methods to improve the application of fertilizers and pesticides $(66.9 \%)$, measures for landscape conservation $(62.7 \%)$ or soil erosion reduction $(62.4 \%)$, to end up with those practices that promote organic farming $(56.8 \%)$ or improve public access to land for leisure activities (54.5\%). Thus, the general opinion is that citizens feel all these agri-environmental measures should be obligatorily implemented among farmers. However, it is important to highlight that the obligation is more strongly felt among those measures with ecological implications (i.e., techniques to improve water use in agriculture and the application of fertilizers and pesticides), followed by those with habitat implications (i.e., reduce soil erosion and preserve flora and fauna), ending with those measures related to amenity implications (i.e., landscape conservation and public access to land for leisure activities) and the promotion of organic farming. We observe how citizens' attitudes towards different agri-environmental property rights vary following Bromley's (1996) classification regarding environmental implications of agriculture.

\footnotetext{
${ }^{5}$ Caution should be taken on the interpretation of these results as individuals were not imposed any kind of budgetary constrain (i.e. they were not asked whether or not they would willing to pay higher taxes to support agri-environmental schemes).
} 
Table 2 Descriptive statistics on how citizens think the current environmental policy should promote the implementation of some agri-environmental measures (percentages)

\begin{tabular}{|c|c|c|c|c|c|c|c|}
\hline \multirow{2}{*}{$\begin{array}{l}\text { Agri-environmental } \\
\text { measure }\end{array}$} & \multicolumn{3}{|c|}{ Voluntary $(\%)$} & \multicolumn{3}{|c|}{ Obligatory (\%) } & \multirow[t]{2}{*}{ Non-resp. (\%) } \\
\hline & VFS (1) & VNFS (2) & Total $(1+2)$ & OFS (3) & ONFS (4) & Total $(3+4)$ & \\
\hline $\begin{array}{l}\text { Techniques to reduce soil } \\
\text { erosion }\left(\mathrm{AEM}_{1}\right)\end{array}$ & 14.3 & 2.5 & 16.8 & 55.3 & 7.1 & 62.4 & 20.7 \\
\hline $\begin{array}{l}\text { Techniques to preserve } \\
\text { flora and fauna }\left(\mathrm{AEM}_{2}\right)\end{array}$ & 12.2 & 1.9 & 14.1 & 60.3 & 9.3 & 69.6 & 16.3 \\
\hline $\begin{array}{l}\text { Techniques to improve the } \\
\text { application of fertilizers } \\
\text { and pesticides }\left(\mathrm{AEM}_{3}\right)\end{array}$ & 13.0 & 4.1 & 17.1 & 54.1 & 12.8 & 66.9 & 16.1 \\
\hline $\begin{array}{l}\text { Techniques to improve } \\
\text { water use in agriculture } \\
\left(\mathrm{AEM}_{4}\right)\end{array}$ & 5.8 & 1.3 & 7.1 & 67.2 & 11.8 & 79.0 & 13.9 \\
\hline $\begin{array}{l}\text { Techniques for landscape } \\
\text { conservation }\left(\mathrm{AEM}_{5}\right)\end{array}$ & 16.2 & 4.0 & 20.2 & 52.3 & 10.4 & 62.7 & 17.1 \\
\hline $\begin{array}{l}\text { Techniques to improve } \\
\text { public access to land } \\
\text { for leisure activities } \\
\left(\mathrm{AEM}_{6}\right)\end{array}$ & 19.9 & 6.5 & 26.4 & 48.1 & 6.4 & 54.5 & 19.1 \\
\hline Organic farming $\left(\mathrm{AEM}_{7}\right)$ & 21.1 & 5.4 & 26.5 & 51.7 & 5.1 & 56.8 & 16.8 \\
\hline Average & 14.6 & 3.7 & 18.3 & 55.6 & 9.0 & 64.6 & 17.1 \\
\hline Sample size**: 1,596 & & & & & & & \\
\hline
\end{tabular}

ONFS, obligatory without financial support; OFS, obligatory with financial support; VNFS, voluntary without financial support; VFS, voluntary with financial support

** This table is made using the total sample of 1,596 individuals which includes both respondents and nonrespondents. For the rest of the analysis only those individuals providing full response to all questions are included $(\mathrm{N}=1,168)$

\subsection{Potential Determinants of Agri-Environmental Awareness: A Review of Hypotheses}

As already mentioned, research into citizens' attitudes in relation to agri-environmental issues based on their preferences for different property rights regimes is rather scarce, providing little guidance on testable hypotheses. Nevertheless, we can use some of the results reported in the literature on social environmental awareness and farmers' willingness to take up agrienvironmental schemes in an attempt to provide a reasonable framework for testing.

Citizens' attitudes towards agri-environmental property rights are certainly influenced by individual needs and interests, ethical values and norms, (self-)perceptions, and undoubtedly by their economic and sociodemographic characteristics. Furthermore, they are directly or indirectly influenced by the social and societal environment, which is composed of a particular political and economic climate and sociocultural habits, norms, and values (Moyano and Garrido 1996; Knierim and Siebert 2004). Thus, general attitudinal agri-environmental variables are related to sociodemographic variables such as age, gender, household composition, social class, and stand on political issues.

Though initially there were suggestions that age is positively correlated with environmental awareness, most studies of the general public have not supported this contention. Rather, the predominant finding has been that age is negatively correlated with environmental concern. Thus, prior research shows that concern for the environment tends to be greater among young age cohorts (Scott and Willits 1991; Cottrell 2003). 
On the other hand, few researchers have paid attention to gender in studies of environmental concern. McEvoy (1972) argues that, because males are more likely to be politically active, more involved with community issues, and have higher levels of education than females, they will be more concerned over environmental problems. Conversely, Passino and Lounsbury (1976) argue than males are more likely than females to be concerned about jobs and economic growth, and thus are less concerned than females with protecting environmental quality. Consequently, there is no agreement on the direction of the relationship between gender and environmental concern.

The presence of family responsibilities is also likely to increase individuals' agrienvironmental awareness if understood as a sustainability approach as individuals become more altruistic and look for a better situation for their children in the future (Andreoni 1990). Agri-environmental awareness can further be constrained with individual social class. Thus, environmental concern is positively associated with social class as indicated by education, income, and occupational prestige. One explanation for this hypothesis is that the upper and middle classes have solved their basic material needs and are thus free to focus on the more aesthetic aspects of human existence. Education has been put to good use as a predictor of environmental knowledge and subsequent behavior. Scott and Willits (1991) found that people with more years of formal schooling have a higher incidence of pro-environmental behavior than do less educated respondents. They also found that income was positively related to pro-environmental behavior, showing that those who are better off financially were more inclined to participate in pro-environmental behavior.

Exposure to environmental issues through occupation is generally assumed to enhance environmental awareness, although farmers decision-making can be modeled purely in terms of the individual acting to maximize profits. However, once again, coexisting with this economic-based literature, is an extensive rural sociological literature in which the result of numerous surveys clearly demonstrated that farmers give great importance to the lifestyle aspects of farming such as independence, following the family tradition, working outdoors (Salamon 1992; Austin et al. 1996; Willock et al. 1999; Costa and Rehman 1999) as for most farmers the uptake of agri-environmental measures pay a relatively insignificant part of everyday farming decisions (Carr 1988).

Several studies have found political ideology or, in this case, stand on political issues, based on a liberalism-conservatism continuum (political left to right), to be significantly related to environmental concern, showing those oriented politically to the left to have greater concern than conservatives (politically oriented to the right) (Scott and Willits 1991; Van Liere and Dunlap 1980, among others).

Furthermore, agri-environmental concern may be context dependent. What people are concerned about can be affected by their actual experience of environmental conditions. Burbank (1995) has suggested "contextual effects do not come about as the result of social composition alone, but result from individuals learning and acting in an environment with an informational bias."

Lastly, environmental attitudes, and intention to act responsibly is assumed to be positively correlated with environmental concern (Hungerford and Volk 1990; McGuire 1992).

\subsection{The Empirical Specification}

We now move a step forward and propose an empirical analysis that aims at testing the validity of citizens' agri-environmental attitude reflected on their preference for different property rights regimes. We focus on the identification of potential determinants of that agri-environmental attitude. To do so, we have followed a twofold approach. Firstly, based 
on the seven agri-environmental measures $\left(\mathrm{AEM}_{j}\right)$ under study we have built a property rights allocation index (PRAI) as follows,

$$
\operatorname{PRAI}_{i}=\sum_{j=1}^{j=7} \mathrm{AEM}_{j i}
$$

where $\mathrm{AEM}_{j i}$ is the value given by participant $i$ in the survey to the agri-environmental measure $j$, coded from 1 (VFS) to 4 (ONFS) following the criterion mentioned above.

The index ranges from 7 to 28 , with lower values (closer to 7 ) indicating a general consensus that farmers should be free to do as they please regarding the implementation of agri-environmental measures, and even that financial rewards should be given to farmers for the provision of agri-environmental benefits to the larger public (i.e., property rights should rest with farmers). Larger values (closer to 28 ) are associated with the idea that the implementation of these techniques and practices should be obligatory for farmers and that they should not have to be paid to provide the agri-environmental benefits (i.e., property rights should rest with society). This index can be used as an ordinal measure of true individuals' agri-environmental attitude so that higher values of the index are equivalent to the belief that overall agri-environmental property rights should rest with the society so as to improve its welfare.

Furthermore, ordinal comparability is assumed, implying that individuals share a common opinion of the definition of agri-environmental attitude. This assumption relies on supporting evidence from two psychological findings. The first is that individuals are able to recognize and predict the satisfaction level of others. In interviews in which respondents are shown pictures or videos of other individuals, respondents were somewhat accurate in identifying whether the individual shown to them was happy, sad, jealous etc. (Diener and Lueas 1999). This also held when individuals were asked to predict the evaluations of individuals from other cultural communities. Hence, it is arguable that there is a common human language of satisfaction and that satisfaction is roughly observable and comparable among individuals. The second finding is that individuals in the same language community have a common understanding of how to translate internal feelings into a number scale, simply in order for individuals to be able to communicate with each other. Respondents have been found to translate verbal labels, such as 'very good' and 'very bad', into roughly the same numerical values (Van Praag 1991). The empirical analysis under the ordinal comparability assumption makes use of latent variable models, such as ordered probit (Greene 1990). ${ }^{6}$ The real axis is divided into intervals $\left(-\infty, \mu_{7}\right], \ldots,\left(\mu_{28}, \infty\right)$, such that the unobserved variable $\operatorname{PRAI}_{i}^{*} \in\left(\mu_{k}, \mu_{k+1}\right]$ if $\mathrm{PRAI}_{i}=k$. The empirical specification is as follows:

$$
\mathrm{PRAI}_{i}^{*}=f\left(X_{\mathrm{sde}_{i}}, X_{c_{i}}, X_{s_{i}}\right)
$$

where $X_{\mathrm{sde}_{i}}$ is the vector of sociodemographic and economic variables and $X_{c_{i}}$ contains contextual variables, while $X_{s_{i}}$ refer to perceived attributes of agri-environmental concern. This will provide a good picture on the determinants of overall agri-environmental attitude.

Second, the approach for examining the factors that influence the choice among different forms of agri-environmental property rights allocation regimes involves estimating multinomial logit regression models (up to seven, one for each agri-environmental measure considered). The different outcomes are allocated the value 1 for "voluntary for farmers and with financial support" (VFS), 2 for "voluntary for farmers without financial support" (VNFS), 3 for "obligatory for farmers with financial support" (OFS), and 4 if the citizen

${ }^{6}$ Linear dependence between the latent variable $\boldsymbol{P R A I} \boldsymbol{I}_{i}^{*}$ and the set of independent variables $\left(x_{i}\right), \beta$ and $\varepsilon_{i}$, and that $\varepsilon \approx N(0,1)$ is further assumed. 
chooses, "obligatory for farmers without financial support" (ONFS). The model is then,

$$
\operatorname{Pr}\left(Y_{i}=j\right)=\frac{\exp \left(\beta_{j}^{\prime} x_{i}\right)}{\sum_{k=1}^{4} \exp \left(\beta_{k}^{\prime} x_{i}\right)}
$$

where $k=1$ (VFS), 2 (VNFS), 3 (OFS), or 4 (ONFS); $x_{i}$ is the vector of covariates for individual $i$ that are considered to affect their attitude towards the alternative implementations of agri-environmental property rights. As mentioned earlier, these covariates will include sociodemographic and economic variables, as well as contextual variables and perceived attributes of agri-environmental awareness. The indicated specification implies independence of the four possible choices, and ONFS is taken as the base category. To interpret the results better, the estimated effects are obtained relative to the effect of the respective variable on the probability of choosing ONFS versus the option considered (namely, VFS, VNFS or OFS). Hence, for example, the probability (or relative risk ratio, RRR) that an individual will choose OFS relative to ONFS is:

$$
\frac{\operatorname{Pr}\left(Y_{i}=3\right)}{\operatorname{Pr}\left(Y_{i}=4\right)}=\exp \left(\beta_{3}^{\prime} x_{i}\right)
$$

The decision on which variables to include is ultimately based on exploratory analysis and data availability. Table 3 reports the definition of the specific variables used for this research, while Table 4 provide some descriptive statistics of the sample under study based on different level of the PRAI index. Further indication as to the meaningfulness of the data on society's attitudes about agri-environmental property rights is the empirical regularities found in the literature of these available variables, to which we now turn.

\section{Results of Multivariate Analysis}

\subsection{Results on Overall PRAI Index}

The next stage of the paper examines the factors that influence individuals' overall attitudes about agri-environmental property rights by using the proposed PRAI index under the ordered probit regression framework shown in Eq. 2. Results are presented in Table 5. Estimated coefficients are tested using $t$-test statistics. The pseudo $R^{2}$ value in our regression in Table 5 is 0.092. Here we measure individuals' agri-environmental attitude (i.e., subjective information). Results are in accordance with the belief and empirical evidence (Ferrer-i-Carbonell 2002; Vera-Toscano et al. 2006) that only about 8-20\% of individual subjective well-being depends on objective variables and thus can be explained (Kahneman et al. 1999). Mainly logical relations appear, but also some noteworthy ones come to light. We observe that this index weakly increases with age. Older people seem to believe that farmers should implement obligatory agri-environmental measures either with financial support or not, but it seems clear that for them property rights should rest with the society and policy must be driven to impose regulations on to farmers actions. Higher income is significantly associated with a higher values of PRAI (property rights should rest with society), while this individual index decreases if a member of the household works in agriculture or the individual lives in a rural area (property rights should rest with farmers), confirming the utilitarian orientation towards the natural environment of these citizens who live closer to the agriculture activity. Lastly, giving greater importance to environmental protection makes you more likely to believe that property rights should rest with society. 
Table 3 Definition of the variables used in the empirical analysis

Variable Description

Dependent variables

Variables regarding agri-environmental awareness ask individuals how some agri-environmental measures should be implemented.

Answers are coded into four categories: 1. It is up to the farmer to implement the selected agri-environmental measure, however he should be rewarded for the provision of such a benefit to the larger public (VFS); 2. It belongs to the farmer's decision-making process to implement or not the selected agri-environmental measure (VNFS); 3. Obligatory for farmers with financial support (OFS); and 4. Obligatory for farmers with no financial support (ONFS).
$\mathrm{AEM}_{1}$
$=$ Techniques to reduce erosion
$\mathrm{AEM}_{2}$
$=$ Techniques to preserve flora and fauna
$\mathrm{AEM}_{3}$
$=$ Techniques to improve the application of fertilizers and pesticides
$\mathrm{AEM}_{4}$
$=$ Techniques to improve water use in agriculture
$\mathrm{AEM}_{5}$
$=$ Techniques for landscape conservation
$\mathrm{AEM}_{6}$
$\mathrm{AEM}_{7}$
$=$ Techniques to improve public access to land for leisure activities
$=$ Ecologic farming and cattle
PRAI
$=$ Property rights allocation index taking the form $\operatorname{PRAI}_{i}=\sum_{j=1}^{j=7} \mathrm{AEM}_{j i}$ ranging from 7 to 28 . Lower values imply that individuals consider that property rights should rest with farmers, while larger values are associated with the idea that the property rights should rest with the society.
Objective personal variables
Age
$=$ age of respondent at date of interview. It further includes age squared.
Gender
$=1$ if gender is male, 0 otherwise.

\section{Household composition variables}

Presence of children

This variable is coded into two categories: 1. Living children even if they are already adults; 0 . otherwise.

\section{Socioeconomic variables}

Income

Self-reported net household income. This variable is coded into four categories: 1 . $\leq 750 € /$ month; 2 . 751-1,250€/month; $3 . \geq 1,251 € /$ month; 4. No income reported.

Education

This variable is coded into four categories: 1. No schooling; 2. Primary studies; 3. Secondary studies; and 4. University level.

Household member in agric.

This variable is coded into two categories: 1 . if a household member works in the agriculture sector; and 0 . otherwise.

Political affiliation

Political affiliation coded into four categories: 1. left oriented; 2. center oriented; 3. right oriented; 4. no political affiliation declared.

\section{Regional variables}

Rural

This variable is coded into two categories: 1 . Rural ( $\leq 5,000$ inhabitants) and; 0. Non-rural (more than 5,000 inhabitants).

Self-reported environmental attitudes and perceptions and other environmental variables

Taxprotec

$=1$ if individuals would be willing to pay more taxes to protect agriculture, and 0 otherwise.

Envatt

$=$ Normalized variable that ranges from 0 to 1 to identify the relative importance individuals give to environmental protection within the various agriculture attributes related to the multifunctionality concept. 
Table 4 Descriptive statistics of the variables used in the analysis (\% when dummies, means when continued variables—-standard errors in brackets)

\begin{tabular}{|c|c|c|c|c|}
\hline Variable & $\begin{array}{l}\text { PR should rest } \\
\text { with farmers }\end{array}$ & $\leftarrow \cdots \rightarrow$ & $\begin{array}{l}\text { PR should rest } \\
\text { with society }\end{array}$ & Total \\
\hline PRAI ranges [from-to] & {$[7-17]$} & {$[18-21]$} & {$[22-28]$} & {$[7-28]$} \\
\hline Sub-sample size & 316 & 703 & 149 & 1,168 \\
\hline \multicolumn{5}{|l|}{ Objective personal variables } \\
\hline Age & $39.43(1.09)$ & $42.18(0.57)$ & $39.36(1.33)$ & $41.08(0.46)$ \\
\hline Male & $0.56(0.02)$ & $0.52(0.01)$ & $0.51(0.03)$ & $0.53(0.01)$ \\
\hline \multicolumn{5}{|l|}{ Household composition variables } \\
\hline $\begin{array}{l}\text { Presence of children in the house- } \\
\text { hold } \\
\text { Socioeconomic variables }\end{array}$ & $0.43(0.03)$ & $0.48(0.01)$ & $0.48(0.03)$ & $0.47(0.01)$ \\
\hline Income $1-\leq 750 € /$ month & $0.12(0.01)$ & $0.13(0.01)$ & $0.06(0.02)$ & $0.12(0.01)$ \\
\hline Income2-751-1,250€/month & $0.25(0.02)$ & $0.24(0.02)$ & $0.20(0.03)$ & $0.24(0.01)$ \\
\hline Income $3-\geq 1,251 € /$ month & $0.20(0.03)$ & $0.22(0.02)$ & $0.30(0.04)$ & $0.22(0.01)$ \\
\hline Income4-No income reported & $0.40(0.03)$ & $0.39(0.02)$ & $0.42(0.05)$ & $0.40(0.01)$ \\
\hline No studies & $0.25(0.02)$ & $0.26(0.01)$ & $0.19(0.03)$ & $0.25(0.01)$ \\
\hline Primary & $0.31(0.03)$ & $0.33(0.01)$ & $0.28(0.04)$ & $0.32(0.01)$ \\
\hline Secondary & $0.28(0.02)$ & $0.24(0.01)$ & $0.30(0.03)$ & $0.26(0.01)$ \\
\hline University & $0.14(0.02)$ & $0.15(0.01)$ & $0.21(0.03)$ & $0.16(0.01)$ \\
\hline Member of household in agriculture & $0.44(0.02)$ & $0.31(0.02)$ & $0.32(0.03)$ & $0.35(0.01)$ \\
\hline Left & $0.18(0.02)$ & $0.15(0.01)$ & $0.14(0.03)$ & $0.28(0.01)$ \\
\hline Centered & $0.45(0.03)$ & $0.42(0.02)$ & $0.46(0.04)$ & $0.26(0.01)$ \\
\hline Right & $0.07(0.01)$ & $0.07(0.01)$ & $0.08(0.02)$ & $0.12(0.01)$ \\
\hline No political affiliation reported & $0.28(0.02)$ & $0.34(0.02)$ & $0.29(0.03)$ & $0.32(0.01)$ \\
\hline \multicolumn{5}{|l|}{ Regional variables } \\
\hline Rural & $0.57(0.04)$ & $0.45(0.03)$ & $0.40(0.05)$ & $0.48(0.02)$ \\
\hline \multicolumn{5}{|l|}{ Environmental related variables } \\
\hline $\begin{array}{l}\text { Taxprotec-individuals willing } \\
\text { to pay more taxes to protect } \\
\text { agriculture }\end{array}$ & $0.16(0.02)$ & $0.15(0.01)$ & $0.19(0.03)$ & $0.16(0.01)$ \\
\hline $\begin{array}{l}\text { Envatt—relative importance } \\
\text { individuals give to environmental } \\
\text { protection within the various agri- } \\
\text { culture attributes related to the } \\
\text { multifunctionality concept }\end{array}$ & $20.54(0.14)$ & $20.68(0.08)$ & $21.33(0.17)$ & $20.73(0.07)$ \\
\hline
\end{tabular}

PR, property rights

\subsection{Results on Different Ways to Adopt Particular Agri-environmental Measures (AEM)}

This stage of the analysis examines the factors that influence citizen's attitudes towards a group of selected agri-environmental measures or good practices, shedding light on whether underlying property rights should rest with society or with the farmer. The estimated results of the multinomial logit model used are presented in Table 6 (coefficients are tested using $t$-test statistics). Each cell presents the relative risk ratios of choosing OFS, VFS or VNFS 
Table 5 Estimates of the ordered probit regression to explain individuals' property rights allocation index $\left(P R A I_{i}\right)$
$* p<0.1 ; * * p<0.05$

$* * * p<0.01$

Omitted categories: Income $1-\leq 750 € /$ month; No studies; Right political affiliation

\begin{tabular}{|c|c|}
\hline Variables & $\hat{\beta}$ \\
\hline \multicolumn{2}{|l|}{ Objective personal variables } \\
\hline Age & $0.0200^{* *}$ \\
\hline $\mathrm{Age}^{2}$ & -0.0001 \\
\hline Male & 0.0622 \\
\hline \multicolumn{2}{|l|}{ Household composition variables } \\
\hline Presence of children in the household & -0.0393 \\
\hline \multicolumn{2}{|l|}{ Socioeconomic variables } \\
\hline Income $2-751-1,250 € /$ month & 0.0678 \\
\hline Income $3-\geq 1,251 € /$ month & $0.2426^{* *}$ \\
\hline Income $4-$ No income reported & -0.0588 \\
\hline Primary & 0.0648 \\
\hline Secondary & 0.0110 \\
\hline University & 0.0348 \\
\hline Member of household in agriculture & $-0.1283^{*}$ \\
\hline Left & 0.0056 \\
\hline Centered & 0.0768 \\
\hline \multicolumn{2}{|l|}{ Regional variables } \\
\hline Rural & $-0.1983^{*}$ \\
\hline \multicolumn{2}{|l|}{ Environmental related variables } \\
\hline Taxprotec & 0.0779 \\
\hline Envatt & $0.0400^{* *}$ \\
\hline \multicolumn{2}{|l|}{ Sample size $(N): 1,168$} \\
\hline Pseudo-R $\mathrm{R}^{2}: 9.2 \%$ & \\
\hline
\end{tabular}

instead of ONFS, which is the base category. Values above unity imply a probability increase of choosing OFS, VFS or VNFS versus ONFS, while values below unity report a probability decrease. Significant results indicated that the chances of choosing OFS relative to ONFS increase at a decreasing rate with age for techniques to preserve flora and fauna and improvement of public access to land for leisure activities ( $\mathrm{AEM}_{2}$ and $\mathrm{AEM}_{6}$, respectively). Thus, while these agri-environmental measures are felt by the general population as more of the voluntary kind, they are perceived as more of the obligatory kind (property rights should rest with society) for older people (other things equal), though they also believe that some financial support should be provided to farmers for the financial harm caused. Men are significantly more likely than females to choose ONFS relative to OFS (roughly by 25\%) and to VNFS (roughly by $60 \%$ ) for $\mathrm{EAM}_{2}$ (i.e., techniques to preserve flora and fauna), holding the rest of variables constant. Thus, for this habitat-related issue, men are more likely to believe that it should be of the obligatory kind as the property rights should fully rest with society. In addition, the presence of children in the household makes parents more likely to choose the OFS (by 55\%) relative to ONFS for techniques to reduce soil erosion $\left(\mathrm{AEM}_{1}\right)$ within the habitat-related issues.

In terms of social-class-related characteristics, the higher the income level the less likely individuals are to support the implementation of voluntary measures for habitat- and ecological-related implications as opposed to obligatory with no financial support $\left(\mathrm{AEM}_{2}, \mathrm{AEM}_{3}\right.$, and $\mathrm{AEM}_{4}$ ). Results for education are similar to those for income, as expressed particularly in 
Table 6 Relative risk ratios for different agri-environmental measures resulting from the multinomial logit regressions

\begin{tabular}{|c|c|c|c|c|c|c|c|c|c|}
\hline \multirow[t]{2}{*}{ Variables } & \multicolumn{3}{|c|}{ Erosion $\left(\mathrm{AEM}_{1}\right)$} & \multicolumn{3}{|c|}{ FLO \&FAU $\left(\mathrm{AEM}_{2}\right)$} & \multicolumn{3}{|c|}{ Agri-Chemical $\left(\mathrm{AEM}_{3}\right)$} \\
\hline & OFS & VFS & VNFS & OFS & VFS & VNFS & OFS & VFS & VNFS \\
\hline \multicolumn{10}{|l|}{ Objective personal variables } \\
\hline Age & 0.98 & 0.94 & $0.89 *$ & $1.06 *$ & 1.04 & 0.99 & 1.03 & 1.00 & 0.94 \\
\hline Age $^{2}$ & 1.00 & 1.00 & 1.00 & $0.99 * *$ & 0.99 & 0.99 & 0.99 & 0.99 & 1.00 \\
\hline Male & 1.16 & 1.23 & 1.03 & $0.73 * *$ & 0.80 & $0.38 * *$ & 1.24 & 1.28 & 0.94 \\
\hline \multicolumn{10}{|c|}{ Household composition variables } \\
\hline Children in household & $1.55^{*}$ & 1.63 & 1.29 & 1.28 & 1.19 & 1.31 & 1.06 & 1.03 & 0.93 \\
\hline \multicolumn{10}{|l|}{ Socioeconomic Variables } \\
\hline Income 2 & 1.26 & 1.19 & 1.13 & 0.65 & 0.79 & 0.73 & 1.22 & 1.17 & 0.49 \\
\hline Income3 & 1.00 & 0.54 & 0.73 & $0.48 *$ & $0.27 * *$ & 0.29 & 0.41 & $0.31 * *$ & $0.07 * * *$ \\
\hline Primary & 0.79 & 1.12 & 0.90 & 0.60 & $0.41 * *$ & $0.35 * *$ & 0.81 & 0.96 & 1.72 \\
\hline Secondary & 1.08 & 1.19 & 1.18 & 0.68 & 0.56 & $0.17 * * *$ & 1.19 & 1.48 & 1.16 \\
\hline University & 0.72 & 0.93 & 0.99 & $0.42 * *$ & $0.28 * *$ & $0.16 * * *$ & 0.82 & 1.18 & 1.36 \\
\hline Household member agric. & 0.99 & 1.42 & 1.04 & 0.78 & 1.09 & 0.86 & 0.90 & 1.08 & 0.71 \\
\hline Left & $1.67 *$ & 1.07 & 2.76 & 1.25 & 0.69 & 5.14 & 0.77 & 0.58 & 0.49 \\
\hline Centered & $2.89 * * *$ & 1.79 & 2.90 & 1.57 & 1.01 & 4.51 & 0.58 & $0.39 * *$ & $0.17 * * *$ \\
\hline \multicolumn{10}{|l|}{ Regional variables } \\
\hline Rural & 0.73 & 1.15 & 1.50 & 0.72 & 1.07 & 0.86 & 1.65 & $3.38 * * *$ & $2.78 * *$ \\
\hline \multicolumn{10}{|c|}{ Environmental related variables } \\
\hline Taxprotec & 1.21 & 1.32 & 0.84 & $1.61 *$ & 1.30 & 0.87 & $0.59 *$ & $0.53 * *$ & 0.84 \\
\hline Envatt & $0.86 * * *$ & 0.91 & 0.96 & 0.93 & $0.85 * *$ & 1.08 & $0.86 * * *$ & $0.89 * *$ & 0.98 \\
\hline \multirow[t]{2}{*}{ Variables } & \multicolumn{3}{|c|}{ Water saving $\left(\mathrm{AEM}_{4}\right)$} & \multicolumn{3}{|c|}{ Landscape $\left(\mathrm{AEM}_{5}\right)$} & \multicolumn{3}{|c|}{ Public access $\left(\mathrm{AEM}_{6}\right)$} \\
\hline & OFS & VFS & VNFS & OFS & VFS & VNFS & OFS & VFS & VNFS \\
\hline \multicolumn{10}{|l|}{ Objective personal variables } \\
\hline Age & 1.03 & 1.01 & 0.93 & 1.02 & 0.97 & 0.98 & $1.04 *$ & 1.01 & 1.02 \\
\hline $\mathrm{Age}^{2}$ & 0.99 & 0.99 & 1.00 & 0.99 & 1.00 & 0.99 & $0.99 *$ & 0.99 & 0.99 \\
\hline Male & 1.11 & 1.09 & 0.89 & 1.00 & 1.07 & 0.65 & 1.02 & 0.97 & 0.79 \\
\hline \multicolumn{10}{|c|}{ Household composition variables } \\
\hline Children in household & 1.12 & 1.06 & 1.42 & 0.80 & 1.12 & 0.58 & 1.11 & 1.07 & 0.80 \\
\hline \multicolumn{10}{|l|}{ Socioeconomic variables } \\
\hline Income2 & 0.87 & 0.89 & 0.57 & 1.47 & 1.68 & 1.14 & 0.82 & 1.17 & 0.91 \\
\hline Income 3 & 0.68 & $0.40 *$ & $0.31 *$ & 1.12 & 1.06 & 0.93 & $0.44 *$ & 0.48 & 0.37 \\
\hline Primary & $0.62 *$ & 0.62 & 1.22 & 0.67 & $0.46 *$ & 0.28 & 1.13 & 0.99 & 0.91 \\
\hline Secondary & 0.64 & 0.56 & 0.97 & 1.04 & 0.51 & 0.40 & 1.34 & 1.39 & 0.95 \\
\hline University & $0.54 * *$ & $0.44 * *$ & 1.06 & $0.49 * *$ & $0.20 * * *$ & 0.42 & 0.97 & 1.14 & $2.00 *$ \\
\hline Household member agric. & 0.96 & 1.23 & 1.19 & 0.90 & $1.68 *$ & 1.93 & 0.75 & 1.12 & 1.05 \\
\hline Left & 1.14 & 0.87 & 1.81 & 1.15 & 0.58 & $\mathrm{X}$ & 1.45 & 1.01 & 0.78 \\
\hline Centered & 1.41 & 1.03 & 1.26 & $1.74 *$ & 0.70 & $X$ & 1.44 & 0.91 & 0.83 \\
\hline
\end{tabular}


Table 6 continued

\begin{tabular}{|c|c|c|c|c|c|c|c|c|c|}
\hline \multirow[t]{2}{*}{ Variables } & \multicolumn{3}{|c|}{ Water saving $\left(\mathrm{AEM}_{4}\right)$} & \multicolumn{3}{|c|}{ Landscape $\left(\mathrm{AEM}_{5}\right)$} & \multicolumn{3}{|c|}{ Public access $\left(\mathrm{AEM}_{6}\right)$} \\
\hline & OFS & VFS & VNFS & OFS & VFS & VNFS & OFS & VFS & VNFS \\
\hline \multicolumn{10}{|l|}{ Regional variables } \\
\hline Rural & 0.74 & 1.23 & 0.67 & 0.68 & 0.81 & $0.29 *$ & 0.90 & 1.18 & 1.06 \\
\hline \multicolumn{10}{|c|}{ Environmental related variables } \\
\hline Taxprotec & 1.06 & 0.73 & 1.11 & 1.05 & 0.85 & 0.62 & 0.97 & 0.83 & 0.56 \\
\hline Envatt & $0.88 * *$ & $0.86 * *$ & 0.99 & $0.86^{* * *}$ & 0.92 & 1.06 & $0.91 * *$ & $0.87 * *$ & 0.87 \\
\hline \multicolumn{10}{|c|}{ Objective personal variables } \\
\hline Age & 1.05 & 1.00 & 0.99 & & & & & & \\
\hline $\mathrm{Age}^{2}$ & 0.99 & 0.99 & 1.00 & & & & & & \\
\hline Male & 0.99 & 0.78 & 0.84 & & & & & & \\
\hline \multicolumn{10}{|c|}{ Household composition variables } \\
\hline Children in household & 1.40 & 1.15 & 0.98 & & & & & & \\
\hline \multicolumn{10}{|l|}{ Socioeconomic variables } \\
\hline Income2 & 0.76 & 0.79 & 0.69 & & & & & & \\
\hline Income3 & 0.49 & 0.81 & 0.44 & & & & & & \\
\hline Primary & 0.73 & 0.63 & 1.86 & & & & & & \\
\hline Secondary & 0.80 & 0.68 & $2.72 *$ & & & & & & \\
\hline University & $0.46^{*}$ & $0.45^{*}$ & $2.57 *$ & & & & & & \\
\hline Household member agric. & 1.06 & 1.31 & 0.98 & & & & & & \\
\hline Left & 1.29 & 0.96 & 0.69 & & & & & & \\
\hline Centered & 0.84 & $0.49 *$ & $0.42 * *$ & & & & & & \\
\hline \multicolumn{10}{|l|}{ Regional variables } \\
\hline Rural & 1.29 & $2.14 * *$ & $3.08 * * *$ & & & & & & \\
\hline \multicolumn{10}{|c|}{ Environmental related variables } \\
\hline Taxprotec & 0.84 & 0.62 & $0.43 * *$ & & & & & & \\
\hline Envatt & $0.87 * *$ & $0.88^{*}$ & 0.95 & & & & & & \\
\hline
\end{tabular}

$\mathrm{X}$ : no observations reported in this category

Omitted categories: Income 1- $\leq 750 € /$ month; No studies; Right political affiliation

Base category: ONFS

* $P<0.1 ; * * P<0.05 ; * * * P<0.01$

the university degree versus no studies category. The higher the education level the less likely individuals are to choose the implementation of any kind of voluntary (with/without financial support) or obligatory with financial support measures for $\mathrm{AEM}_{2}, \mathrm{AEM}_{4}$ and $\mathrm{AEM}_{5}$. For these agri-environmental measures their implementation should be obligatory and with no financial support, following the idea that property rights should totally rest with society. However, this is not the attitude observed for measures to improve public access to land for leisure activities $\left(\mathrm{AEM}_{6}\right)$ and the promotion of organic farming $\left(\mathrm{EAM}_{7}\right)$, which are felt to be more of the voluntary kind by the more educated people.

Contrary to expectations, no strong significant evidence was found for any AEM and the presence of a household member working in agriculture. However, we observe how rural residency has strong significant effect on agri-environmental attitudes with rural residents being more likely to support the implementation of voluntary (with/without financial sup- 
port) measures regarding improvements in the application of fertilizers and pesticides $\left(\mathrm{AEM}_{3}\right)$ related to ecological implications, and the promotion of organic farming $\left(\mathrm{AEM}_{7}\right)$, supporting the utilitarian orientation towards the natural environment because of their potential direct involvement with more extractive occupations such as farming.

Regarding political affiliation some interesting results were found for those who declared to have central political affiliation. On the one hand, these individuals were less likely to choose the implementation of voluntary measures as opposed to ONFS to improve the application of fertilizers and pesticides $\left(\mathrm{AEM}_{3}\right)$, and the promotion of organic farming $\left(\mathrm{AEM}_{7}\right)$. For them, the property rights on these measures should totally rest with society, showing more of a politically right affiliation. However, on the other hand, they are also more likely to support the implementation of OFS measures to avoid erosion $\left(\mathrm{AEM}_{1}\right)$ and, to a less extent, landscape conservation $\left(\mathrm{AEM}_{5}\right)$ with financial support, showing more of a left-leaning affiliation. This result opens an interesting debate on what political affiliation means in Andalusia. This debate is however out of the scope of this study.

Lastly, environmental attitudes and intention to act responsibly also play a significant role in the estimations, as the greater the importance you give to environmental protection the more likely you are to choose the ONFS option. Thus, for these individuals almost all agrienvironmental measures considered should be obligatorily implemented by farmers with no financial support (property rights should rest totally with society). No conclusive results were found for those individuals willing to pay more taxes to protect agriculture.

\section{Summary and Conclusions}

The increased social awareness about the relationship between agriculture and the environment has driven the movement towards a significantly active agri-environmental policy in developed countries. Previous studies have examined the attitudes, psychology, and decision-making processes of farmers as direct participants in agri-environmental schemes; nonetheless empirical research into citizens' position has been limited to date. This study contributes to the literature by examining further insights into overall citizens' agri-environmental attitudes towards the environmental implications of agriculture under different property rights regimes (understood as the social dynamic institutions upon which agriculture-environment-society interactions are based), as well as the factors influencing these attitudes. The characteristics of the "2005 Survey on Individuals' Opinion of Rurality and Agriculture in Andalusia (Agrobarometre 2005)" allows for the empirical testing of this previously unexamined issue. Results will certainly contribute to agri-environmental policy evaluation and development.

Overall, we perceive that a large majority of Andalusians think these measures should be obligatorily implemented by farmers. However there is also a general opinion on the promotion of compulsory but subsidized agri-environmental measures reflecting that, while individuals believe agri-environmental property rights should rest with society so as to improve its welfare, this should not be interpreted in absolute terms as they also believe such an obligation implies a change in the current status quo (property rights currently resting on farmers) with a significant loss for farmers, who should thus be compensated.

Furthermore, significant differences exist between the various agri-environmental measures under study. Thus, the implementation of obligatory measures is more strongly supported for those measures with ecological implications (property rights should rest with society), followed by those with habitat implications, and finally those measures related to amenity implications and the promotion of organic farming. This result suggests that 
agri-environmental measures should be put in place taking into account their potential environmental implications. Thus, financial rewards should be given to farmers for measures with habitat or amenity implications while partial or no financial support should be available for those measures with implications for ecological processes.

On the whole, this research proves to be a valuable tool to identify factors determining individuals' attitudes towards agri-environmental property rights that can certainly help policy-makers to provide a customized, better response to social demands on this matter. However, while the overall results support the development of an active socially sensitive agri-environmental policy, the degree to which the implementation of such a policy certainly satisfies society's demand is still open to debate. A few aspects certainly need further investigation, namely:

- Taking into account the budgetary constraints in the design and implementation of an effective agri-environmental policy, to what extent would citizens be willing to pay higher taxes to support agri-environmental schemes?

- Equally, in relation to the balance between environmental sustainability and agriculture production, it is worth further investigating the extent to which the implementation of agri-environmental measures would significantly affect the strategic economic role of agriculture as a provider of food and income among the rural population and, as a result, whether Andalusian society would continue supporting an active agri-environmental policy.

- Lastly, it is also worth questioning whether more information/formation on agri-environmental issues would change individuals' attitudes and perceptions about environmentagriculture interactions.

Once again, answers to these questions would definitely contribute to the development of an effective agri-environmental policy and consequently would significantly improve citizens' well-being.

Acknowledgements This research was supported by the Regional Government of Andalusia (Junta de Andalucía) and by the Ministry of Education and Science (MEC) through project FUTURPAC (AGL200605587-C04-01). The authors would like to acknowledge the comments provided by two reviewers on an earlier version of this paper that have allowed a more detailed and clear presentation of the research; the usual disclaimer applies.

\section{References}

Andreoni J (1990) Impure altruism and donations to public goods: a theory of warm-glow giving? Econ J 100(401):464-477

Austin EJ, Deary IJ, Gibson GJ, McGregor MJ, Dent JB (1996) Attitudes and values of Scottish farmers: 'yeoman' and 'entrepreneur' as factors, not distinct types. Rural Sociol 61:464-474

Bromley DW (1996). The environmental implications of agriculture. Staff Paper 401, Department of Agricultural and Applied Economics, University of Wisconsin-Madison

Bromley DW (1997) Constitutional political economy: property claims in a dynamic world. Contemp Econ Policy 15(4):43-55

Bromley DW, Hodge I (1990) Private property rights and presumptive policy entitlements: reconsidering the premises of rural policy. Eur Rev Agric Econ 17(2):197-214

Buller H, Wilson GA, Höll A (2000) Agri-environmental policy in the European Union. Aldershot, Ashgate

Burbank M (1995) How do contextual effects work? Developing a theoretical model. In: Eagles M (ed) Spatial and contextual models in political research. Taylor and Francis, London, pp 165-178

Christman J (1994) The myth of property. Oxford University Press, Oxford

Carr S (1988). Conservation of farm: conflicting attitudes, social pressures and behaviour. Unpublished Ph.D. Thesis, Open University 
Clark AE (1997) Job satisfaction and gender: why are women so happy at work? Labour Econ 4(4):341-372

Clark JR, Jones A, Potter CA, Lobley M (1997) Conceptualising the evolution of European Unions' agri-environmental policy: a discourse approach. Environ Plan 29:1869-1885

Costa FP, Rehman T (1999) Exploring the link between farmers' objectives and the phenomenon of pasture degradation in the beef production systems of Central Brazil. Agric Syst 61(1):135-146

Cottrell SP (2003) Influence of sociodemographics and environmental attitudes on general responsible environmental behaviour among recreational boaters. Environ Behav 35(3):347-375

Diener E. Lucas R. E (1999) Personality and subjective well-being. In: Kahneman D, Diener E, Schwarz N (eds) Well-being: the foundations of Hedonic Psychology. Russell sage Foundation, New York, Chap. 11

EEA, European Environment Agency (2004) High nature value farmland. Characteristics trends and policy challenges. European Environment Agency, Copenhagen

EEA, European Environment Agency (2006) Integration of environment into EU agriculture policy-the IRENA indicator-based assessment report, EEA Report No 2/2006, European Environment Agency, Copenhagen

Ferrer-i-Carbonell A (2002). Income and well-being: an empirical analysis of the comparison income effect. Tinbergen Institute Discussion Paper 2002-019/3.

Ferrer-i-Carbonell A, Frijters P (2004) How important is methodology for the estimates of the determinants of happiness? Econ J 114:641-659

Greene W (1990) Econometric analysis. MacMillan, New York

Hungerford HR, Volk TL (1990) Changing learner behaviour through environmental education. J Environ Educ 21(3):8-21

IESA, Instituto de Estudios Sociales Avanzados de Andalucía, (2006) Opinión Pública, Agricultura y Sociedad Rural en Andalucía' (Agrobarómetro 2005), Informe Síntesis. Informes y Monografías E-0304. IESA-CSIC, Córdoba

Ilbery BW, Bowler IR (1998) From agricultural productivism to post-productivism. In: Ilbery BW (ed) The geography of rural change. Longman, Harlow, pp 57-84

Kahneman D, Diener E, Schwarz N (1999) Foundations of hedonic psychology: scientific perspectives on enjoyment and suffering. Russell Sage Foundation, New York

Knierim A, Siebert R (2004) The BIOfACT German report on WP3. Institute of Socioeconomics, ZALF, Müncheberg

McEvoy JIII (1972) The American concern with the environment. In: Burch WRJr, Cheek NHJr, Taylor L (eds) Social behavior, natural resources, and the environment. Harper and Row, New York, pp 214-236

McGuire JR (1992) An examination of environmental attitudes among college students. Unpublished master's thesis, Pennsylvania State University, University Park

Morris C, Potter C (1995) Recruiting the new conservationists: farmers' adoption of agri-environmental schemes in the UK. J Rural Stud 11(1):51-63

Moyano E, Garrido F (1996) Spain: social players in the implementation of agri-environmental policy. In: Whitby M (ed) The European environment and CAP reform: policies and prospects for conservation. CAB International, Wallingford, pp 87-96

OECD (1998) Agriculture and the environment: issues and policies. OECD, París

Oñate JJ, Malo JE, Suárez F, Peco B (1998) Regional and environmental aspects in the implementation of Spanish agri-environmental schemes. J Environ Manage 52(3):227-224

Ortiz D, Ceña F (2002) Efectos de la política agroambiental de la Unión Europea en el mundo rural. Información Económica Española 803:105-116

Ortiz D, Estruch V (2004) The role of agri-environmental measures in the definition of property rights. In: Van Huylenbroeck G, Verbeke W, Lauwers L (eds) Role of institutions in rural policies and agricultural markets. Elsevier, Amsterdam, pp 335-348

Passino EM, Lounsbury JW (1976) Sex differences in opposition to and support for construction of a proposed nuclear power plant. In: Ward LM, Coren S, Gruft A, Collins JB (eds) The behavioral basis of design, book 1. Dowden, Hutchinson and Ross, Stroudsburg, pp 180-184

Primdahl J, Peco B, Schramek J, Andersend E, Oñate JJ (2003) Environmental effects of agri-environmental schemes in Western Europe. J Environ Manage 67(1):129-138

Salamon S (1992) Prairie patrimony. University of North Carolina Press, Chapel Hill

Scott D, Willits FK, (1991) Environmental concern of Pennsylvania citizens: data from a statewide survey. Technical Report A.E. and R.S. 219, Department of Agricultural Economics and Rural Sociology, Pennsylvania State University

Tawney RH (1948) The adquisitive society. Harcourt, Brace and World, Inc., New York

Tremblay KR, Dunlap RE (1978) Rural-urban residence and concern with environmental quality: a replication and extension. Rural Sociology 43:474-91 
Van Liere KD, Dunlap RE (1980) The social bases of environmental concern: a review of hypotheses, explanations and empirical evidence. Public Opin Q 44(2):181-197

Van Praag Bernard MS (1991) Ordinal and Cardinal Utility. An integration of the two demensions of the Welfare Concept. J Econometrics 50: 69-89

Vera-Toscano E, Ateca V, Serrano R (2006) Building financial satisfaction. Soc Indic Res 77:211-243

Whitby M (1996) The European environment and CAP reform: policies and prospects for conservation. CAB International, Wallingford

Whitby M (2000) Challenges and options for the UK agri-environment. J Agric Econ 51(3):17-32

Willock J, Deary IJ, Edwards-Jones G, Gibson GJ, McGregor MJ, Sutherland A, Dent JB, Morgan O, Grieve $\mathrm{R}$ (1999) The role of attitudes and objectives in farmer decision-making: business and environmentallyoriented behaviour in Scotland. J Agric Econ 50(2):286-303

Wilson GA (1996) Farmers environmental attitudes and ESA participation. Geoforum 27(2):115-131

Wilson GA, Hart K (2001) Farmer participation in agri-environmental schemes: towards conservation-oriented thinking? Sociol Ruralis 41(2):254-274

World Bank (1997) Five years after Rio: innovations in environmental policy, environmentally sustainable development studies and monographs series no.18 (June). World Bank, Washington 